\title{
The Effect of Exchange Rate Fluctuation on International Trade in Rwanda
}

\author{
Gervais TWAMUGIZE ${ }^{\mathrm{a}}$, Zhang Xuegong ${ }^{\mathrm{b}}$, Abeid Ahmed Rmadhani ${ }^{\mathrm{c}}$ \\ ${ }^{a}$ School of Economics, Huazhong University of Science and Technology, Wuhan, China \\ ${ }^{b}$ School of Economics, Huazhong University of Science and Technology, Wuhan, China \\ ${ }^{c}$ School of Busuness, The state University of Zanzibar, Tanzania
}

\begin{abstract}
This paper is empirically examine the effect of exchange rate fluctuation on international trade in Rwanda employing annually time series data from 1990-2014. The Vector Error Correction (VECM) model has been used to capture both short and long-run relationships and the findings show the insignificant relationship between exchange rate and export as well as between exchange rate and import. The Granger causality test have been used to study the causal effect of one variable on other variables, basing on the test results we found that GDP to export and exchange rate to export hold bi-directional cause to each other. Whereas, on the other side we found that only GDP to import hold bi-directional causation between them. This paper finds evidence that exchange rate fluctuation is the main factor that affects the level of international trade measure in terms of export and import flows in Rwanda. It appears that if policy makers wish to promote export and to decrease import in order to improve the balance of trade in Rwanda, they have to keep an open eye on steady appreciation of the exchange rate and to reduce volatility.
\end{abstract}

Keywords: Exchange rate Fluctuation, International trade, VECM, Rwanda

\section{Introduction}

Rwanda is a small, landlocked country in East Africa and one of the most densely populated of Africa. With GDP per capita of $760 \$$, Rwanda is classified a low income country. The agricultural sector is one of the key sectors in the economy, as the sector account $34 \%$ of GDP and employs $80 \%$ of the labor force. The service sector accounting $52 \%$ of GDP has grown steadily in recent years. Especially the financial, education and health sectors have seen high growth rate recently. Rwanda's export sector is underdeveloped; exports of goods and services contributed most highly to the sector. Primary export products are coffee and tea. Minerals are increasingly exported, but a part of them may be hindered by a new law that came into force in March 2011. This law forbids all Rwandan exporters to export minerals originating from conflict areas in Democratic Republic of Congo, to be in compliance with US law requiring minerals to be conflict-free. Main blocks of destination of Rwanda's exports are Europe and Africa. Imports are more than twice of exports and more diversified, consisting of consumer, capital and intermediate goods. Biggest merchandise import partners are Kenya and Uganda. The Rwandese economy has recovered considerably since the 1994 genocide but still vulnerable to exogenous shocks, in spite of improved macroeconomic performance over the past decade, the economy is still challenged by high external debt burden, vulnerability to terms of trade shocks and one of the lowest saving rates in Africa, at 3 percent of GDP. As consequence the economy relying on heavily on foreign currency dominated aid flows. In 2013, the Rwandan franc (RFW) continued to follow a depreciating trend against US dollar with several short periods of stability. Accordingly, the facto exchange rate arrangement was reclassified from Crawl-like arrangement to other managed arrangement. (IMF, Annual report, 2014) .In Rwanda where foreign aid flows to government account for around half of all foreign exchange inflows, and were the private financial sector is less developed, the central bank is the decisive player and to large the degree still the market maker. The lower level of financial sector and capital market development in Rwanda would suggest that this country continue to experience significant insulation from portfolio capital flows and the associates risks of the build-up of speculative pressured on the currency. Rwanda's current account improved by 5.8\% in 2013-2014 to a deficit of USD 522.83 million from a deficit of USD 554.64 million recorded during 2012-2013. The improvement is mainly attributable to higher current transfers which increased by $9.5 \%$ to USD 877.15 million from USD 800.71 million during 2012-2013. However, the trade, services and income deficit declined to USD $1,399.98$ million from $1,355.26$ million, while only trade balance worsened to USD 1.212.93 million in 2013-2014 from USD 1.195.56 million in the previous fiscal year due to the increase of imports compared to exports (BNR, 2014)

The study is organized into five chapters; the first chapter is about the general introduction of the whole research. The second chapter is about literature review on generalities of the effect of exchange rate fluctuation on international trade in Rwanda. The third chapter deals with the methodology used in this research and data. The fourth chapter describes the research findings and their analysis and takes an attempt of interpreting the 
main findings of the study based on stated objectives. Finally, the fifth chapter deals with the conclusion and recommendations of this study.

\section{Review Of Literature}

Flavio Vilela Vieira Ronald (2016), investigated the relationship between real effective exchange rate volatility and exports, and also investigated the effect of international financial crisis of 2008 on exports; employing sample size of 106 countries with data from 2000 to 2011 and the estimation technique used is system GMM (Generalized Method of Moments). The findings reveal that for exports volume there is an increase in the mean and the standard deviation, suggesting that the export volume has a moderate increase after international financial crisis of 2008 and that for two measures of exchange rate volatility there is an increase in the mean but not the standard deviation when comparing the pre-and-post crisis periods implying that there is evidence that on average the volatility was higher for post-crisis period but there is less dispersion among countries.

The results also show that there is evidence supporting the role of real effective exchange rate volatility in explaining export volume only when oil exporting countries are part of the sample, this implies that an increase (decrease) in exchange rate volatility reduces (increase) export volume. But when oil exporting countries are removed from sample there is no evidence supporting the effect of exchange rate volatility on exports. Concerning the effect of international financial crisis of 2008 on export volume, the results confirm that it has played a significant role and it is on average slightly $(0.14 \%)$ higher after the crisis when compared to the previous period of (2000 to 2007)

Junwook Chi and Keo Cheng (2015) examined the short and long-run impacts of real income, bilateral exchange rate and exchange rate volatility on Australia's maritime export volume to its major Asian trading partners, using quarterly data for the period of 2000: Q12013:Q2, including two measure of real exchange rate volatility (GARCH and mean-adjusted relative change measures). First, results indicate that Australia's maritime exports are predominantly driven by the economic growth in its major Asian trading partners (China, Japan, South Korea, India...) in both short and long run, implying that continuing economic growth in Australia's major Asian trading partners' economies, especially China and India will increase the volume of Australia's maritime exports. Second, results find the evidence that the exchange rate fluctuation has a statistically significant long-run impact in the majority of cases, suggesting that exchange rate volatility appears to be an important factor affecting maritime export volume. Taufing Choudhry and Syed S.Hassan (2015) studied the role of exchange rate volatility in determining the UK's real imports from three major developing countries (Brazil, China, and South Africa), using monthly data from January 1991 to December 2011 and the asymmetric autoregressive distributed lag (ARDL) model, the results reveal that there is a long run relationship between UK's imports and exchange rate volatility along with other determinant variables such as UK's real income and relative import price ratio. Normalized coefficient for the nominal and real exchange rate volatilities from the asymmetric ARDL method show a large number of inverse relationships with respect to third country exchange rate volatilities, which are represented by the dollar/pound rate volatility, the results find a negative impact on imports in almost all cases. Florian Verheyen (2012) investigated whether the exchange rate variability proxied by measures of moving standard deviation or GARCH (1.1) model, is crucial for exports to the united states for eleven countries of the European union. Using a simple export demand model, the results revealed that the real exchange rate reduces exports, while US demand stimulates them. Furthermore, the exports react more than proportionally to rising US demand. The relationship between exchange rate volatility and trade flows has been investigated by many scholars around the world. According to Yusaku Nishimura and Kenjiro Hirayama (2013), investigated the effect of RMB-JPY volatility on Japan-China trade with a special emphasis on the period after July 2005 when the exchange rate regime was reformed, by using two measures of exchange rate volatility: the one is derived by AR-EGARCH of exchange rate volatility the other is simply standard deviation of daily exchange rate changes during a given month, then they applied the ARDL approach to estimate short-run and long run effects of various variables on China's and Japan's exports to each other. The findings revealed that Japan's exports to China are not affected by the volatility, but that the exports of China to Japan were negatively affected by the volatility during the reform period. Therefore, China's reform of the exchange rate regime had adversary effect on her exports to Japan when the volatility was high. Generally, Chinese exports are subject to influences from the exchange rate. Dimitrios Seneris and Nicholas Tsounis (2013), examined the effect of exchange rate volatility for a set of two countries, Croatia and Cyprus on exports during the period of 1990: Q1-2012: Q1, applied a multivariate co integration error correction model for two countries and two different measures of volatility. Their empirical analysis revealed that although exchange rate volatility when measured as the simple standard deviation of log effective exchange has no impact on the level of exports for both Croatia and Cyprus. However, when alternative measure is used there is an indication of a stronger effect from movements of the exchange rate to the level of exports. It reported a negative relationship between exchange rate volatility and the level of exports for Croatia. Kanchana Senana Yake and Ahmed 
Abdulhusain (2010), investigated the impact of exchange rate movements on trade flows between Sri Lanka and China through a regression model which include the change in real bilateral exchange rate, changes in income and exchange rate volatility using quarterly time series data for the period of 1993: Q1 to 2007: Q4, they found that the depreciation of Sri Lanka Rupee against Chinese RMB has a positive significant effect on Sri Lanka's exports to China while depreciation of Rupee has negative effects on its imports from China. Exchange rate volatility has negative significant effects for both exports and imports. Jungho (2014), studied the effect of exchange rate fluctuations on Korean trade with the US, an autoregressive distributed lag (ARGDL) approach to co integration was applied and found that $75 \%$ of total exports are highly responsive to the bilateral exchange rate volatility and third country effects in both long and short-run. On the other hand it is found that Korea's imports are relatively insensitive to those three factors in both short and long-run. As conclusion the depreciation of Korean currency could increase the export volume of Korea's major products in the short and long-run. August C. Arize, Thomas Osang and Daniel J. Slottje (2000), investigated empirically the effect of exchange rate volatility on the export flows of thirteen less developed countries (LDC's) over the quarterly period of 1973-1996, the findings shows that there is a negative and statistically significant long-run relationship between export flows and exchange rate volatility in each of thirteen least developed countries. The results shows that the exchange rate volatility has a short-run effect on export flows and there are substantive causal relationships in which changes in exchange rate volatility granger cause changes in exports. Wanhui Jiang (2014), examined the effect of nominal RMB exchange rate volatility on economic growth in China over the period of between 1981 to 2012, through the ADF stationary test, the co-integration test, and the associated econometric model, stated that RMB nominal exchange rate fluctuation is the main factor that affects China's exports and imports. The results revealed that in long-run, devaluation of RMB will have a positive impact on the foreign trade. Chee-Wooi Hooy, Siong-Hook Law and Tze-Haw Chan (2015), studied the impact of RMB real exchange rate on ASEAN disaggregated exports to China, through dynamic ordinary least square (DOLS) estimator over the period of 1994-2008. The findings are structured as follow; first, income elasticity is positive and statistically significant in all models and it is increasing by the level of technology, second, the fluctuation in RMB real exchange rate have a positive and significant impact on ASEAN's exports to China, third, the RMB impact on disaggregated exports by technology level is mixed, for finished goods exports, higher technology exports are sensitive to RMB depreciation, which is consistent with the income effect, while for ports and components exports, the lower technology exports actually have a greater exposure to RMB depreciation.

\section{Methodology}

The study employs Vector Error Correction approach using annually time series data from 1990 to 2014, obtained the following variables Exchange rate (EXCH), Exports (EXP), Imports (IMP), Gross Domestic Product (GDP) and Money supply (M3). The import (IMP), export (EXP) and GDP data were collected from World Data Bank (World Economic Indicators), Real exchange rate (EXCH) data were collected from UNCTAD (statistics division), While Money Supply(M3) data were collected from National bank of Rwanda (BNR) Eviews8 Econometric Software was used to analyze data.

The study examines the genuine of the following hypotheses according to the theoretical argument presented above;

Hypothesis 1: the exchange rate fluctuation has the effect on export and import trade in Rwanda

Hypothesis 2: there is a long-run relationship between the exchange rate and volume of export-import in Rwanda.

In order to estimate the effect of exchange rate on exports and imports in Rwanda, we employ Vector Error Correction Model (VECM). By considering the theoretical approach, the functional form of the model to be employed in this study is specified as follow;

EXPt $\square \mathrm{f}(\mathrm{EXCHt}, \mathrm{GDPt}, \mathrm{MSt}) \square U i$......

IMPt $\square \mathrm{f}(\mathrm{EXCHt}, \mathrm{GDPt}, \mathrm{MSt}) \square V i$.

Equation (1) and (2) are specified in functional form, where;

EXPt ; Export

IMPt ; Import

EXCHt ; Exchange rate

GDPt; Gross domestic product

MSt ; Money supply

$U i$ And $V i$; are error terms

Economic time series are often analyzed after computing their logarithms or the change in their logarithms. The purpose of log-linear $(\mathrm{L})$ is because of the value of some variables such as export, import is in millions, the nominal exchange rate is in percentage while money supply is billions. There was therefore the use of logarithm in the model to bring the variables to the same base since the variables were measured in different 
ways. Secondary, many economic series such as gross domestic product (GDP) exhibit growth that is approximately exponential, that is, over the long run the series tend to grow by a certain percentage per year on average. If so, the logarithm of the series grows approximately linearly. Thirdly, the standard deviation of many economic time series approximately proportional to its level, that is. The standard deviation is well expressed as a percentage of the level of the series. If so, then the standard deviation of the logarithm of the series is approximately constant. In either case, it is useful to transform the series so that the changes in transformed series are proportional (or percentage) changes in the original series, and this is achieved by taking the logarithm of the series.

In order to avoid non stationary problem in time series data, we employ the Augmented Dickey-Fuller (ADF) Test to test the stationary status of the variables used in the equation above. The presence of unit root in the series means that the variable is not stationary, hence the degree or order of integration is one or higher. While the absence of unit root means that the time series under consideration is stationary. To study the absence of random walk in the time series under consideration, a unit root test is performed. This is done in order to find out the nature of stationary of the data and in order to avoid spurious regression model. The table below indicates results of the test on the time series data using Augmented Dickey-Fuller test

\section{Step number 2: Johansen and Juselius Co-integration test}

Sometimes two or more series have the same stochastic trend in common. In this special case, referred to as co integration, regression analysis can reveal long-run relationship among time series variables. According to Johansen (1991), co integration can be used to confirm whether there exists a linear long-run economic relationship among variables. For time series that are individually I (1), That is, contain a unit root. The co integration of the series is an important condition for the existence of long-run relationship.

\section{Step number 3: Vector Error Correction model (VEC)}

The VECM was developed to observe and estimate both long-run and short run effect of one time series on another, and to test the stability of the long-run. According to Engle and Granger (1991) indicated that when the variables are co integrated, the dynamic relationship can be specified by an error correction representation in which an error correction term (ECT) calculated from long-run equation has to be added in order to capture both short-run and long-run relationships.

In this study, we used time series data for 25 years, That is, from 1990 to 2014. I have chosen to source some of the data from World Bank because it has reputation of providing accurate country data for many countries around the world. The variables in the regression are as follow;

Exports: exports indicate the value of all goods and services exported or traded to the rest of the world. For example; the value of merchandise, freight, insurance.... They do not include compensation of the employees and investment income (formerly called factor services) and transfer payments.

Imports: Imports show the value of all goods and services imported from the rest of the world. For example; merchandise, freight, insurance, transport... They do not include compensation of the employees and investment income (formerly called factor services) and transfer payments.

Exchange rate: The nominal exchange rate is the number of units of domestic currency that can purchase a unit of given foreign currency.

Money supply: money supply is the entire stock of currency and the liquid instruments in a country economy as of a particular time..

\section{Result}

In order to avoid non stationary problem in time series data, we employ the Augmented Dickey-Fuller (ADF) Test to test the stationary status of the variables used in the equation above. The presence of unit root in the series means that the variable is not stationary, hence the degree or order of integration is one or higher. While the absence of unit root means that the time series under consideration is stationary. To study the absence of random walk in the time series under consideration, a unit root test is performed. This is done in order to find out the nature of stationary of the data and in order to avoid spurious regression model. The table below indicates results of the test on the time series data using Augmented Dickey-Fuller test.

Table 4.1: Unit Root Test

\begin{tabular}{l|l|l|l|l|l|l|}
\hline \hline Variables & \multicolumn{1}{c}{ t-statistic } & \multicolumn{2}{c}{ t-statistic } & \multicolumn{2}{c}{ Probability IO } \\
\hline Lexports & -2.607052 & 0.2804 & $\mathrm{I}(\mathrm{O})$ & -4.773990 & 0.0047 & $\mathrm{I}(1)$ \\
\hline Limports & -1.374328 & 0.8424 & $\mathrm{I}(\mathrm{O})$ & -4.432026 & 0.0097 & $\mathrm{I}(1)$ \\
\hline Lexch & -1.576893 & 0.7691 & $\mathrm{I}(\mathrm{O})$ & -4.363982 & 0.0117 & $\mathrm{I}(1)$ \\
\hline Lgdp & -0.194616 & 0.9239 & $\mathrm{I}(\mathrm{O})$ & -6.358234 & 0.0003 & $\mathrm{I}(1)$ \\
\hline Lms & -3.020823 & 0.1473 & $\mathrm{I}(\mathrm{O})$ & -5.317984 & 0.0020 & $\mathrm{I}(1)$ \\
\hline
\end{tabular}

Source: Author's computation, Eviews 8 
The Augmented Dickey-Fuller (ADF) test results in the table above indicate that all the variables have unit root. The results show that all variables (Lexports, Limports, Lexchange rate Lgdp and Lms) are not stationary in levels. As proven by their t-statistic and their probability values high and less than 0.05 levels, the variables become stationary at first difference.

Sometimes two or more series have the same stochastic trend in common. In this special case, referred to as co integration, regression analysis can reveal long-run relationship among time series variables. According to Johansen (1991), co integration can be used to confirm whether there exists a linear long-run economic relationship among variables. For time series that are individually I (1), That is, contain a unit root. The co integration of the series is an important condition for the existence of long-run relationship. According to Jams H.Stock and Mark W.Watson (introduction to econometrics), there are three ways to decide whether two variables can plausibly be modeled as co integrated; use experts knowledge and economic theory, graph the series and see whether they appear to have a common stochastic trend, and perform statistical tests for co integration. Johansen-Juselius approach provides a test for co-integration and reveals number of cointegration relationships. This procedure uses two tests to figure out the number of cointegration equations: the trace and the maximum Eigen value tests. The co-integration test results of the johansen co integration test are given in the following tables.

Table 4.2: Johansen Co-integration test results

\begin{tabular}{|c|c|c|c|c|}
\hline Hypothesized & Eigen value & Trace statistic & $5 \%$ Critical value & Prob. \\
\hline \multicolumn{5}{|l|}{$\begin{array}{l}\text { Value } \\
\text { No of } C E(s)\end{array}$} \\
\hline None* & 0.778521 & 63.82775 & 47.85613 & 0.0008 \\
\hline At most1 & 0.578286 & 29.15693 & 29.79707 & 0.0591 \\
\hline At most2 & 0.304771 & 9.298093 & 15.49471 & 0.3385 \\
\hline At most 3 & 0.039932 & 0.937280 & 3.841466 & 0.3330 \\
\hline
\end{tabular}

Source: Author's computation, Eviews 8.0 econometric software used.

Trace test shows 1 co integration equation at 0.05 level, * indicates rejection of null hypothesis at the 0.05 level.

Table 4.3: Johansen Co integration (Maximum Eigen values) test results

\begin{tabular}{lcccc}
$\begin{array}{l}\text { Hypothesized } \\
\text { CE(S) }\end{array}$ & Eigen value & Max.Eigen & $\mathbf{0 . 0 5}$ critical value & Prob. Value statistic No. of \\
\hline None* & 0.778521 & 34.67082 & 27.58434 & \\
& & & & \\
At most1 & 0.578286 & 19.85884 & 21.13162 & 0.0052 \\
& & & & \\
At most2 & 0.304771 & 8.360813 & 14.26460 & 0.3432 \\
At most3 & 0.039932 & 0.937280 & 3.841466 & 0.330 \\
\hline
\end{tabular}

Source: Author's computation, Eviews 8 econometric software used

Maximum Eigen value test shows 1 co integration equation at 0.05 level, * indicates rejection of null hypothesis at the 0.05 level.

Table 4.4: Johansen Co-integration test results

\begin{tabular}{|l|l|l|l|l|}
\hline Ypothesis No. of CE(S) & Eigen value & Trace statistic & 0.05 critical value & Prob. Value \\
\hline None* & 0.664768 & 56.27947 & 47.85613 & 0.0066 \\
\hline At most1 & 0.526331 & 31.14203 & 29.79707 & 0.0348 \\
\hline At most2 & 0.441780 & 13.95535 & 15.49471 & 0.0842 \\
\hline At most3 & 0.023473 & 0.546320 & 3.841466 & 0.4598 \\
\hline
\end{tabular}

Source: Author's computation, Eviews 8 econometric software used

Trace test shows two (2) co integration equations at 0.05 levels As this research is divided into two models (exports and imports) models, the co integration test results given in the table 2, 3, and 4 are also for two equations. For exports, both Trace and Maximum Eigen Value Tests indicate one (1) co integration equation at $5 \%$ level of significance. The results show the existence of one co integration among the variables. This assures 
the existence of a fixed long-run relationship among exports as dependent variables, real exchange rate, Gross Domestic Product (GDP) and Money Supply of Rwanda. For imports, Trace test shows two co integration equations at 5 percent significance level. The results confirm the existence of long-run relationship among imports taken as dependent variable, real exchange rate, Gross Domestic Product (GDP) and Money supply of Rwanda. From the results of co integration tests we discussed in the previous part of this research, base on the findings of all co integrating vector among the variables, here we estimate the long-run relationship for exports and imports. Both equations were derived from normalized vectors. The long-run relationship for exports and imports and their explanatory variables was given by normalizing exports and imports separately and dividing each of the co integrating coefficients by the coefficients of exports and imports respectively. According to the model of export above, we find one long-run relationship between export and other variables; the exchange rate of Rwanda applies negative effect on exports. The findings reveal that increase of exchange rate all things being equal leads to a decrease of exports. The coefficient of -3.2248 implies that a unit increase in exchange rate of Rwanda will decrease the exports of 3.2248. The GDP exerts a positive effect on exports; the findings support exports-led growth hypothesis (Marisen O and Sarah Pilcher, 2014) insinuating that an increase in exported merchandise leads to subsequent increase in GDP. The findings in some of the literature state that the similar increase in GDP goes with an increasing percentage of exports. The coefficient of 3.0452 implies that a unit increase in economic growth of Rwanda ceteris paribus will increase exports of 3.0452. Money supply exerts a negative effect on exports; the findings imply that a unit increase in money supply will decrease the exports of 3.756563. On the imports side, the equation shows that a unit increase in exchange rate leads to fall of imports of 0.7472 , the findings agree with the expected sign. The economic justification is that when the nominal exchange rate falls holding price levels in both domestic and foreign country constant, the real exchange will also fall. When the real exchange rate is low domestic resident will want to buy fewer imported goods (Mankiew, p151). The GDP exerts negative effect on imports which implies that as the economic growth increases by $1 \%$, the imports will fall of 2.0727 in long run. The money supply shows a positive effect on the import. The finding implies that a unit increase of money supply leads to increase of imports of 0.8671 . The VECM was developed to observe and estimate both long-run and short run effect of one time series on another, and to test the stability of the long-run. According to Engle and Granger (1991) indicated that when the variables are co integrated, the dynamic relationship can be specified by an error correction representation in which an error correction term (ECT) calculated from long-run equation has to be added in order to capture both short-run and long-run relationships. This error correction terms has to be statistically significant with a negative sign.

Table 4.5: Vector Error Correction Model (VECM1)

\begin{tabular}{|c|c|c|c|c|}
\hline Variables & Coefficient & St.Error & T-statistic & Prob. Value \\
\hline D(Lexports(-1)) & -0.287108 & 0.480203 & -0.59789 & 0.5527 \\
\hline D(Lexports(-2)) & 0.410378 & 0.44508 & 0.92203 & 0.3611 \\
\hline D(Lexch(-1)) & 1.579696 & 1.32194 & 1.19498 & 0.2380 \\
\hline D(Lexch(-2)) & 0.156113 & 0.50895 & 0.30673 & 0.7406 \\
\hline D(LGDP(-1)) & 1.268770 & 0.56011 & -2.26523 & 0.0280 \\
\hline D(LGDP(-2)) & 0.216048 & 0.64874 & 0.33303 & 0.7406 \\
\hline D(LMS(-1)) & 2.581973 & 1.19740 & 2.15613 & 0.0361 \\
\hline D(LMS(-2)) & 0.668639 & 1.32740 & 0.50372 & 0.6196 \\
\hline ECM & 0.492500 & 0.470641 & 1.046432 & 0.3006 \\
\hline \multicolumn{5}{|c|}{$\begin{array}{cc}\mathbf{R}^{2}: 0.470767 & \text { DW: } 2.053320 \\
& \text { Table 4.6: Vector Error Correction Model (VECM2) } \\
\end{array}$} \\
\hline Variables & Coefficient & St.EnTor & T-statistic & Prob. Value \\
\hline D(Limports(-1)) & 0.250115 & 0.388805 & 0.64454 & 0.5223 \\
\hline D(Limports(-2)) & -0.611881 & 0.35913 & -1.70380 & 0.0949 \\
\hline D(Lexch(-1)) & -0.184464 & 0.64297 & -0.28690 & 0.7754 \\
\hline$D(\operatorname{Lexch}(-2))$ & -0.680264 & 0.43238 & -1.57332 & 0.1222 \\
\hline D(LGDP(-1)) & 0.421467 & 0.17210 & 2.44900 & 0.0180 \\
\hline D(LGDP(-2)) & -0.216049 & 0.31452 & -0.68692 & 0.4954 \\
\hline D(LMS(-1)) & -0.156303 & 0.63287 & -0.24697 & 0.8060 \\
\hline D(LMS(-2)) & 1.145111 & 0.60892 & 1.88056 & 0.0661 \\
\hline ECM & -0.290429 & 0.253613 & -1.145166 & $\mathbf{0 . 2 5 7 8}$ Activate \\
\hline
\end{tabular}

$\mathbf{R}^{2: 0.698459}$ DW: 1.626454

From table 5 and table 6 above, the coefficients of the error correction terms are $0.492500,-0.290429$ for exports and imports respectively. Coefficients values are not statistically significant. The insignificance of these coefficients shows the absence of co integrating relationships in the short run. As indicated by the table above, exports at lag one and lag two are not significant. At lag one, exports apply a negative effect on current 
exports of 0.2871 whereas, exports have a positive sign at lag two. The results reveal that the insignificant effect of exports on current exports insinuates that the former exports cannot be used to batten the future period. The exchange rate at both lags (lag one and lag two) shows insignificant effect on exports and possesses a positive sign. The existence of a positive value indicates the positive effect on exports all things being equal. The increase in exchange rate will lead to 0.156113 increases in exports. GDP lagged one is statistically significant, which means that it has a significant effect on exports and ha a positive sign. The result show that a unit increases in gross domestic product (GDP) will lead to increase exports of 1.268770. While it is statistically insignificant and has a positive sign at lag two. Money supply is statistically significant at lag one and hold a positive sign. The result indicates that increase of money supply of Rwanda will lead to an increase in exports of 2.581978. While it is insignificant at lag two.

On the imports side, import is not significant at both lags, it holds a positive sign at lag one while it has a negative sign at the second lag. The results reveal that the insignificance of import insinuates that former import cannot be used to batten the future period. The exchange rate at lag one and lag two are not significant and hold a negative sign at both lags. This means that exchange rate has no significant effect on imports. GDP lagged one is significant, the result shows that one unit improves or increase of GDP lead to an increase to an increase in imports of 0.421467 . While it is statistically insignificant at lag two and possesses a negative sign. Money supply is not significant at lag one with a negative sign while it is statistically insignificant with a positive sign at lag two.

\section{Impulse response function}

From the Vector error correction approach, the effect of variables shocks is illustrated through the impulse response functions which graph the impact of shock to one variable on the other variable over time. As we have four variables there are 16 impulse response functions (4 variable shocks each affecting 4 variables). We will limit our discussion to the important shocks and effects of these shocks key economic variables.

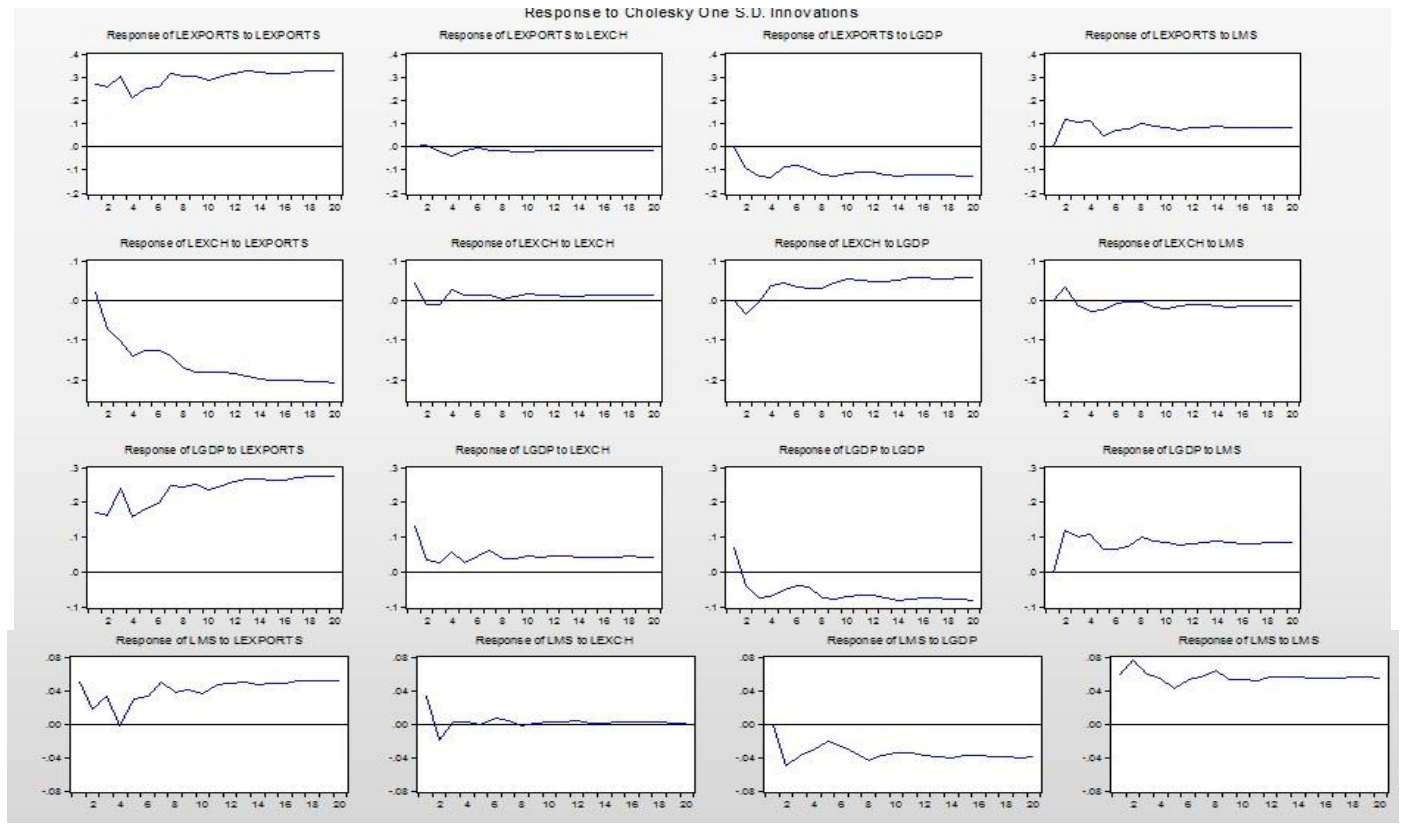

On the exports model, the impulse response function shows the impact of a negative shock to exchange rate on export in the second and the fifth panel, this negative shock on exports leads to a negative effect of exchange rate on export. The panel 9 shows the positive shock of export to GDP, this when the increase in Export is positively related to the increase in GDP. Whereas, in future until 10 years exchange rate will be positive related to GDP as indicated by panel 10, while panel 4 and 12 indicate the positive shock of money supply on export and Gross Domestic Product (GDP) respectively. 


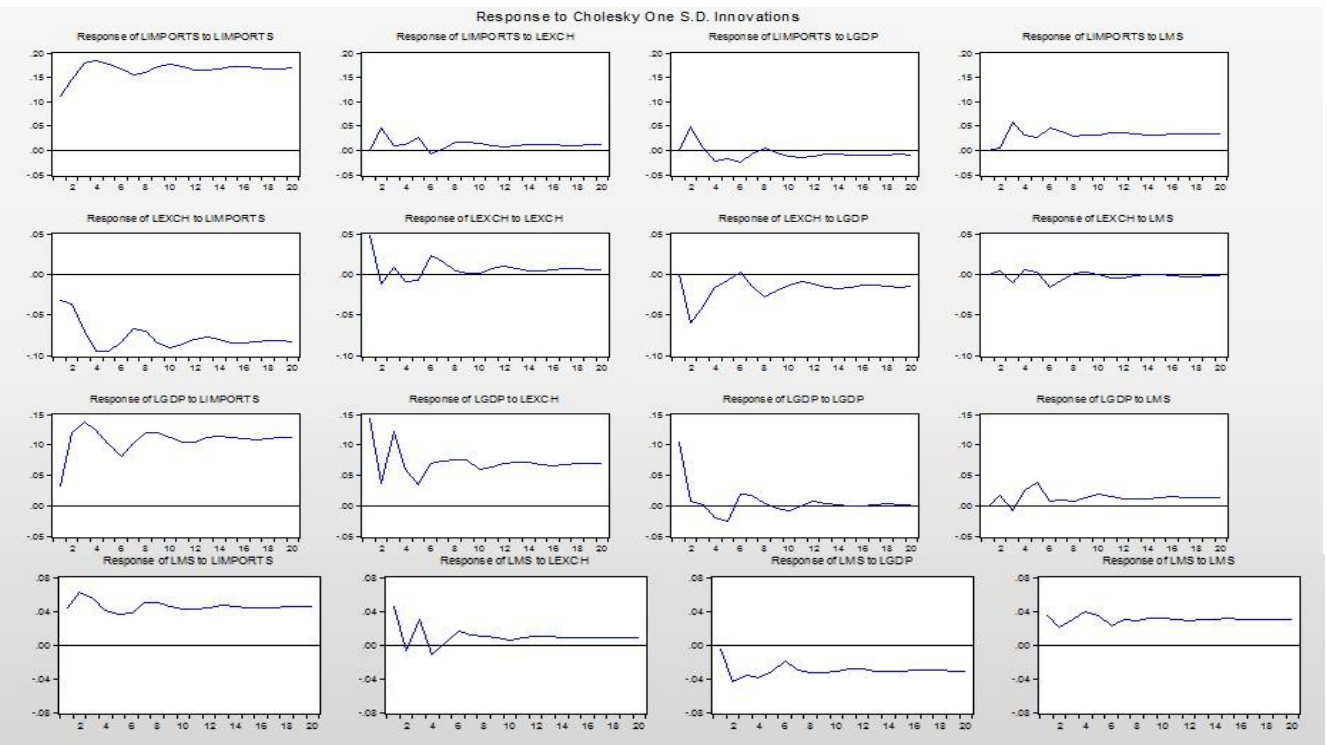

The figure above shows the positive shock to exchange rate on imports, the panel 2 shows the increase in exchange rate accompanied by the increase in imports. The panel 3 shows that if there is a positive shock of GDP to import, import will first increase for four (4) years then decrease and increase again until it becomes steady. The panel 9 of this figure shows a positive shock of import to GDP, this lead to a significant relationship between GDP and imports.

\section{Granger causality test}

According to Damodar N. Gujarati (2003), regression analysis about the dependence of one variable on other variables; it does not necessarily mean causation. In other words, the existence of a relationship between variables does not prove causality or direction of influence. But in the regressions involving time series data, the situation may be somewhat different because, as one author puts it, time does not run backward. That is, if event A happens before event $\mathrm{B}$, then it is possible that $\mathrm{A}$ is causing $\mathrm{B}$. however; it is not possible that $\mathrm{B}$ is causing $\mathrm{A}$. in other words; events in the past can cause events to happen today. Future events cannot.

To explain the granger test, we will consider the often asked question in macroeconomics: is it exchange rate that causes export ( $E X C H \square E X P$ ) or is it export that causes exchange rate ( $E X P \square E X C H$ ), where the arrow points to direction of causality. The granger causality test assumes that the information relevant to the prediction of the respective variables EXCH and EXP is contained solely in the time series data on these variables.

Table 4.7 the results of Granger causality test on export

\begin{tabular}{|l|l|l|l|}
\hline Null hypothesis & F-statistic & Probability & Decision \\
\hline LGDP does not granger cause Lexport & 3.34858 & 0.0580 & Reject \\
\hline Lexport does not granger cause LGDP & 8.17851 & 0.0030 & Reject \\
\hline LMS does not granger cause Lexport & 6.73231 & 0.0066 & Reject \\
\hline Lexport does not granger cause LMS & 2.23416 & 0.1359 & Accept \\
\hline LEXCH does not granger cause Lexport & 6.82537 & 0.0062 & Reject \\
\hline Lexport does not granger cause LEXCH & 7.37484 & 0.0046 & Reject \\
\hline
\end{tabular}

Source: author's computation, Eviews 8.0

Table 7 indicates that exchange rate $(\mathrm{EXCH})$ to export, and GDP to export bidirectionally granger cause each other. This can be proved by the significance of their respective F-statistic and probability values. In contrast, money supply uni-directionally granger cause export

Table 4.8 the results of Granger causality test on import

Null hypothesis
\begin{tabular}{|l|l|l|l|}
\hline LGDP does not granger cause Limport & F-Statistic & Probability & Decision \\
\hline Limport does not granger cause LGDP & 10.3652 & 0.0010 & Reject \\
\hline LMS does not granger cause Limport & 3.41487 & 0.0553 & Reject \\
\hline Limport does not granger cause LMS & 2.50034 & 0.1101 & Accept \\
\hline LEXCH does not granger cause Limport & 0.04644 & 0.9547 & Accept \\
\hline Limport does not granger cause LEXCH & 2.59005 & 0.1027 & Accept \\
\hline
\end{tabular}

Source: author's computation, Eviews 8.00 
Table 8 shows that only GDP and import have bi-directional causation between them. Whereas money supply (MS) to import and exchange rate $(\mathrm{EXCH})$ to import are individually independent. In other word, neither uni-directional nor bi-directional causation exist. Though, there is no causality between money supply to import or exchange rate to import.

\section{Conclusion}

This study investigates the effect of exchange rate volatility on the export and import in Rwanda by using annually time series data from 1990 to 2014. Based on the literature review, we find that the effect of exchange rate volatility on foreign trade is an empirical issue rather than theoretical because no theory itself cannot determine the relationship between exchange rate volatility and foreign trade. Results base on unit root test indicate that all variables have got a unit root at levels and become stationary at first difference. The co integration test results of both trace and maximum Eigen values show the existence of co integration equation at 0.05 levels. i.e. trace and maximum eigen values indicate the existence of long-run relationship between dependents and independents variables. Base on the findings of all co integrating vector among the variables we estimated the long-run relationship for export and import and their explanatory variables from normalized vectors, we find that an increase of exchange rate all things being equal leads to a decrease of export while an increase in exchange rate leads to a decrease of imports.

The Vector Error Correction (VECM) results indicate that the coefficients of error correction term are not statistically significant, this insignificance of error correction term implies the absence of short-run relationship between export and other variables. Exchange rate is statistically insignificant and holds a positive sign at both lags. While other variables such as GDP at lag one and money supply at lag one are also significant. On the import side, the VECM results indicate that there is no short-run relationship between import and other variables. The findings revealed that the increase in exchange rate or devaluation of Rwandan currency is negatively related to exports while the increase in exchange rate indicates the negative effect on import in longrun.. On the imports side, the results indicate the increase in exchange rate leads affect the level of import negatively. The Granger causality test have been used to study the causal effect of one variable on other variables, basing on the test results we found that GDP to export and exchange rate to export hold bi-directional cause to each other. Basing on the findings, there is a strong evidence that exchange rate is the main factor affecting international trade in Rwanda as it negatively affects export as well as import flows. The research investigated the effect of exchange rate volatility on export and import in Rwanda, this research finds evidence that there is a long-run relationship among export, import and exchange rate suggesting that exchange rate volatility appears to be an important factor affecting international trade in Rwanda. Establishing the relationship between exchange rate volatility and export/import may help to formulate trade and exchange rate policy. The findings indicate that currency fluctuation has an adverse effect on both export and import flows. The establishment of fluctuations in the exchange rate and quantitative determination of the magnitude of the effect of such volatility might help in focusing on how to alleviate the impact. It appears that if policy makers wish to promote export and to decrease import in order to improve the balance of trade in Rwanda, they have to keep an open eye o steady appreciation of the exchange rate and to reduce volatility. Our findings support the importance of including the impact of exchange rate volatility in international trade flow models to avoid the issue of omitted-variables bias. To this end, I suggest that future research on this topic or related topic should be done at disaggregated level.

\section{References}

[1] Florian Verhen (2012), bilateral exports from euro zone countries to US-does exchange rate volatility play role "international review of economics and finance vol 24"

[2] Yusaku Nishimura and Kenjiro Himaraya (2013), does the exchange rate volatility deter Japan-China trade? "Japan and world economy vol 25-26"

[3] Dimitrios Seneris and Nicholas Tsounis (2013), exchange rate volatility and foreign trade: the case for Cyprus and Croatia "Procedia economics and finance vol 5"

[4] Kanchara Seranayake and Ahmed Abdulhusain (2010), exchange rate movements' effect on Sri Lanka-China trade “journal of Chinese economy and foreign trade studies vol 3

[5] Jungho Baek (2014), exchange rate effects on Korean- US bilateral trade "research in economics"

[6] Augustine C. Arize, Thomas Osang and Daniel J. Slottje (2000) exchange rate volatility and foreign trade: evidence from thirteen LDC's, "journal of business and economic statistics vol 18

[7] Chee-Wooi Hooy, Law Siong-Hook and Chan Tze-How (2015), the impact of the RMB real exchange rate on ASEAN disaggregated exports to China, "Economic modeling vol 47

[8] Flavio Vilela Vieira Ronald MacDonald (2016), "exchange rate volatility and exports: a panel data analysis" Journal of Economic studies, Vol. 43

[9] Junwook Chi and Seu Keow Cheng (2016), “do exchange rate volatility and income affect Australia's maritime export flow to Asia" transport policy, volume 47

[10] Taufiq Choudhry (2005), "exchange rate volatility and United States exports: Evidence from Canada and Japan" journal of the Japanese and international economics

[11] James H. Stock and Mark W. Watson, Introduction to econometrics

[12] OZTURK, Ilhan (2006),"exchange rate volatility and trade" international journal of applied Econometrics and Quantitative studies.vol3-1 
[13] Thomas Osang, Chuck A Arize and Daniel Jonathan Slottje (2000), "Exchange rate volatility and foreign trade: Evidence from thirteen LDC's" journal of Business and Economic Statistics

[14] WenShwo Fang, YiHao Lai and Stephen M.Miller (2009), "does exchange rate risk affect exports asymmetrically? Asian evidence" journal of international Money and Finance, 28

[15] Yayon Zelekha and Ohad Bar-Efrat (2011), "the link between exchange rate uncertainty and Israel export to US: 2SLS and co integration approaches" research in economics, vol 65 